DOI: 10.2478 /ausfm-2014-0033

\title{
Sensations of the Past: Identity, Empowerment, and the British Monarchy Films
}

\author{
Zsolt Győri \\ Debrecen University (Hungary) \\ E-mail: gyorizs@yahoo.co.uk
}

\begin{abstract}
Royal bio-pics have always enjoyed a high priority among cinematic representations of British history and taken a lion's share in defining Britishness to audiences at home and abroad. These historical narratives never render national identity by capturing the past of historians, instead reconstruct the past as a mirror of contemporary reality and in a way as to satisfy their audience's demand for both romantic qualities and antiquarian nostalgia, for sensations they regard their own. The author's basic assumption is that such cinema does not represent history but exploits spectatorial desire for a mediated reality one inhabits through the experience of an empowered identity. The first part of the article examines how private-life films (a subgenre of royal bio-pics) mythologized and idealized Tudor monarchs in the 1930s, while in the second part, contemporary representatives of the subgenre are analysed as they portray the challenges of the Monarchy in its search for a place within modern British identity politics. Analysed films include The Private Life of Henry VIII (Alexander Korda, 1933), The Private Lives of Elizabeth and Essex (Michael Curtiz, 1939), Mrs Brown (John Madden, 1997), The Queen (Stephen Frears, 2006), and The King's Speech (Tom Hooper, 2010). ${ }^{1}$
\end{abstract}

Keywords: British royal bio-pics, the psychologization of history, The Private Lives of Elizabeth and Essex (1939), Mrs Brown (1997), The Queen (2006), and The King's Speech (2010).

\section{Introduction}

Although British screen culture is rich in historical depictions, rarely does it address topics generally considered by the academic historian as Britain's chief contribution to Western civilization. Apart from the zenith of the Empire and their heroic resistance of the nation during WWII, there is little attention paid

1 The publication is supported by the TÁMOP-4.2.2/B-10/1-2010-0024 project. The project is co-financed by the European Union and the European Social Fund. 
to the development of the parliamentary system, Puritanism, the making of the Empire, the industrial revolution, or the trade unions. This should however not come as a surprise: the moving image has not gained worldwide popularity as a stimulant of the intellect; its sensations have always appeared closer to visceral emotionality and instant entertainment than the exercises of an analytical mind. Thus abstract socio-political, religio-political, and socio-cultural phenomena have been overshadowed by historical representations rooted in the concrete entities of historical figures, love affairs, the zeitgeist of an era, great conquests and defeats. Corresponding cinematic genres - respectively the bio-pic, the costume melodrama, the period film and the historical epic - render the past as an immersive field of genuine drama and attraction, and although they might be criticised for their poetic license, historical cinema, as Martha W. Driver notes, "provides immediacy and simultaneously appeals to the imagination, engaging the viewer in the past and involving him emotionally and imaginatively in the action on the screen" (2004, 19). It is this imagination I set out to discuss in this article.

In the introductory chapter of Remaking the Middle Ages Andrew B. R. Elliott describes three problem areas that need to be considered when examining (or for that matter criticizing) cinema's use of history. These are narrative, montage, and ideology. The first involves techniques of arranging and fitting events into a narrative scheme, giving them formal coherency. The second concerns the ordering of events, the way moments are pieced together in a historical narrative. Ideology, as the third factor shaping representations of the past - that "foreign country whose features are shaped by today's predilections, its strangeness domesticated by our own preservation of its vestiges" (Lowenthal 1985, xvii) - is of chief concern for me. In the wake of Lowenthal's and others illuminative arguments, there is now a definite agreement among film scholars that historical cinema should not be thought of as historiographic interpretation but epistemological mirror of the age (its national culture, social structure, system of filmmaking, identity crisis) that produces it. Kara McKechnie argues in similar vein when she suggests that "a history film tells us more about the time in which it was made than the time in which it is set" $(2002,218)$, and so does Andrew B. R. Elliot: "filmmakers trying to bring to life a historical past are frequently prone to reflect the cultural, political and social trends most prominent in the climate of the film's production" (2011, 22). The films I am about to analyse prove the above points and address issues lying outside the world of historians, simply because they themselves turn away from the knowable essences of the past. What makes these films widely popular is not a strict and original scientific methodology, but finely tuned techniques 
of dramatization and schematization, the framework of a cinematic memory that needs to be readjusted from time to time. In a sense such memory knows little, or next to nothing about the past, yet possesses expert knowledge of the audience addressed, that is, knows how to shape and mould - above all - the materiality of the past so that viewers will want to identify with and remember it.

The representation of the past as something deeply embedded in materiality is a common feature of all the above mentioned historical genres. Stifling colours, voluptuous bodies, flamboyant draperies framed by a string of painterly miseen-scénes, flaming passions heightened by music and additional effects populate the screen in order to indoctrinate the eyes and ears under "the religion of sensuous appetites" (Marx 2002, 33) - the very definition Marx used to describe commodity fetishism. The fetishization of hypersensual representations leads to the proliferation of such material images in historical cinema which offer points of pleasurable immersion for audiences. The research of Laura U. Marks made important advance in the field of material and haptic images/visuality which she differentiates from purely visual, dis-embodied perception. In both The Skin of the Film: Intercultural Cinema, Embodiment, and the Senses and Touch: Sensuous Theory and Multisensory Media she questions the supremacy of optical visuality and argues that meaning is not only generated at the level of conceptual seeing through idealization and symbolization but via "response in terms of touch, smell, rhythm, and other bodily perceptions" (Marks 2000, xvii). Marks argues that haptic visuality generates meaning in the "flow between sensuous closeness and symbolic distance" (2002, xiii), where the audiovisual properties of cinema are not maintained without sensation becoming non-hierarchical, folded, and multi-sensorial in nature. Within these shifting relations of distance and presence, the spectator's position is best understood as a "dynamic subjectivity" (Marks $2002,3)$. The maker of haptic cinema destabilizes prescriptive categories and representational conventions that would determine how the material is to be read, instead invites the spectator to "[build] toward its object, brushing into its pores and touching its varied textures" (Marks 2002, xv), an act which can seriously undermine dominant notions of subjectivity. In view of linking haptic visuality to generic cinema Marks is more cautious, and so should we. The sensuous qualities of historical representations tend to be superficially woven into the image, they rarely undertake the hard task to go beyond commodity fetishism and uncover the hidden meanings of a historical age through its embodied sensation. Marks notes that commercial media has serious constraints in comprehending multisensory pleasures, "for most Western cinema, these sources are supplements to the many 
other representational resources it has at its disposal" (Marks 2000, xii), resources - one might add - which inscribe ideology into the image.

Under the hegemony of commodity fetishism the materiality of the past is not only instrumentalized and subordinated to the logic of consumption but is also mummified. What permeates historicizing imagination is, first and foremost, an ideological materiality. No serious examination of cinematic memory can escape taking into consideration the extent to which films are themselves ideological effects of making history consumable in the very manner museums achieve this aim. In a sense the spectator of historical films is someone under the spell of, what Lowenthal has called the "pastness of the past' ${ }^{2}$ or, what Nietzsche has termed, the agent of an antiquarian historical sense: someone "who will greet the soul of his people as his own soul even across the wide, obscuring and confusing centuries; and power of empathy and divination, of scenting an almost cold trail, of instinctively reading aright the past however much it be written over [...] knowing oneself not to be wholly arbitrary and accidental, but rather as growing out of the past as its heir, flower and fruit and so to be exculpated, even justified, in one's existence" (Nietzsche 1980, 19-20).

The films I propose for discussion wear the materiality of the past - something the eyes find pleasing to touch and feast on - as a mask; yet these masks (as Nietzsche suggests) also fulfil our desire to be protected from the loud roaming of contemporary history, and express one's reverence for old customs, welltested values and beliefs. Such desire was never more apparent than in the British cultural policy of the 1980s, spearheaded by "heritage industry: a potent marketing of the past as part of the new enterprise culture, a commodification of museum culture" (Higson 2003, 1). Part of this industry was a culturally English but financially international cinema with preference towards "particular types of stories that narrate the nation imaginatively, narratives that are capable of generating a sense of national belonging in their audiences" (Higson 2011, 1). The fact that heritage cinema emerged in the decade when the public discourse on a deepening identity crisis became increasingly ideological ensure further legitimacy for the argument, in view of which cinema always pictures and narrates the past in order to offer ideologically-embedded empowerment for audiences. Understood in these terms, empowerment is always partial towards particular values and ideals, in the very manner Belén Vidal in her recent book on

2 Addressing the contemporary fixation of preservation, Lowenthal argues that "it is no longer the present of the past that speaks to us, but its pastness. Now a foreign country with a booming tourist trade, the past has undergone the usual consequences of popularity" (1985, xvii). 
heritage cinema suggests: "architectural sites, interior design, furnishing and, in general, the mise-en-scène of objects, setting and period settings not just become a conduit for narrative and characterisation but carry an ideological effect: they help construct a sense of Englishness according to a certain bourgeois ideal of imperil tradition, stability and propriety" (Vidal 2012, 9).

Heritage films might have taken a lion's share in constructing Britain's modern national(ist) iconography, nevertheless the first homogenous group of films that both fetishized the materiality of the past and rendered it is a consumable image were the monarchy biopics, or so-called 'private-life films'3 made in the 1930 s. These films engendered prototypical empowerment narratives which made the past consumable in the form of ideological materiality. From the classical period I will examine two films by Hungarian émigrés, Alexander Korda's The Private Life of Henry VIII (1933) and Micheal Curtiz's The Private Lives of Elizabeth and Essex (1939) and show how they mythologized but also humanized the person of the monarch while reasserting and offering empowerment for traditional notions of gender. Philippa Lowthorpe's TV movie The Other Boleyn Girl (2003) will be analysed as the antithesis of mythical representations. Last I examine the recent renaissance of private-life films through the examples of John Madden's Mrs Brown (1997), Stephen Frears's The Queen (2006), and Tom Hopper's The King's Speech (2010) which portray royal characters while analysing their personalities. Royal characters within this latter representational paradigm are rendered as suffering in their respective ways from the conflict between the intimacy of private life and the remoteness of institutional identity. My focus is how identity crises are always resolved from within, that is, how these characters (re)gain the respect of the public after having understood their responsibility as role-models towards them.

\section{The Mythologizing-Melodramatic Approach and its Recent Critique}

Alexander Korda's The Private Life of Henry VIII openly admits to being interested in the historical figure of the Tudor monarch as the masculine hero of popular memory - the mythical Henry. Already the entrée of Charles Laughton, as the exact replica of Hans Holbein the Younger's famous portrait of the king, puts things on the right track and introduces audiences to a culturally constructed quasi-mythological image of Henry as the mixture of a Renaissance prince and

$3 \quad$ For details on the historical inaccuracies of films made in line with the private film formula see Chapman (2005, 28-30). 
a Rabelaisian figure: a narcissistic man of excess as far as courtly, culinary, and carnal pleasures are concerned. Henry's overstated self-assuredness and outspoken misogyny - apparent in statements like "My first wife was clever, my second was ambitious. Thomas, if you want to be happy, marry a girl like my sweet little Jane. Marry a stupid woman" - is balanced by his ever-present good spirits and cheerful vulgarity (in the vein of Shakespeare) which his court and all of Merrie England seem to share. For Korda Henry's "life story belongs to the people of later generations, not because it is in the history books, but because it is crude and generous and vulgar enough to establish an England about which history books could be made" (Lejeune quoted in Chapman 2005, 21-22), in other words, he is at the centre of a mythologized history which nonetheless serves as a point of empowerment. Such history would have a lot in common with storybooks and fairytales for children more the same as at the end of the film the aged, white-bearded and obese Henry seated by the fireplace and covered in blankets recalls popular images of Father Christmas. Chapman is right to suggest that "the film validates the institution of monarchy, a central plank of consensus politics" $(2005,31)$, nevertheless Henry's representation as a genuine national folk hero is constructed through xenophobia, insularity, sentimental nostalgia, and the romantic myth of egalitarianism. Yet most relevant is masculinity, not only evident in his bottomless sexual appetite, but also in his straightforward hotheadedness and the open mockery of (table) manners amongst others. Higson's argument about the attractions of recent medieval and early modern historical films seems to apply Korda's film too: "the unmodern setting thus legitimates what now seems socially or culturally transgressive, what might otherwise be considered censorable representations" (Higson 2011, 216). Henry's masculinity, even if for audiences it remained no more than a fantasy of masculinity, proved empowering and complemented with his above listed other attitudes and values was willingly embraced by economically hard-hit audiences beyond England, in Great Britain and the US alike. In a sense Kordaesque, populist-mythological or, for that matter, sentimentally nostalgic history for the working classes was a product of the post-Depression world of surging unemployment rates, of disillusioned people and the crisis of traditional gender hierarchies. For them the England of Henry VIII exemplified a reality more tolerable than their own, thus warmly welcomed a cinema which would serve as a corrective mirror and offer them projected illusion of the people they would have liked to be.

Michael Curtiz's The Private Lives of Elizabeth and Essex directly follows on Korda's path, not only because he uses the private life formula to depict the love- 
hate relationship between Elizabeth I and the Earl of Essex but for portraying Tudor England as a Romantic realm fetishized in its material splendour. As a national heroine the character of Elizabeth is constructed through the virtues of self-restraint and sacrifice. Unlike Henry, her attractions and desires will remain unfulfilled, de-eroticized, and idealized, nonetheless empowering. Already in the very first scene Curtiz makes explicit the temptations awaiting the queen: the grand parade of the victorious Earl of Essex is portrayed through the voyeuristic gaze of the ladies-in-waiting, one of whom fascinatedly exclaims: "Oh, it must be wonderful to be a man." Be that the shiny armour, the tight trousers and the flawless makeup, the male body is offered for spectacle, yet its pleasures are never realized. For these lustful bodies belong to egoistic, power-hungry warmongers, who - as in the case of Essex - wish to take Elizabeth as "simply a woman" as the king's queen. Elizabeth's recognition, that there is an unresolvable conflict between her public and private identities, disallowing her to be both a queen and a woman, eventually leads to the suppression of her feminine love. Yet another, highly idealized love and a symbolic 'marriage' is realized: "There is another love greater than the one I have for you [...] England. That is my greatest and most enduring love. And when I think what you would do to my country if you were king, I will see you dead, yes and your soul condemned to eternity forever." Arriving to cinemas in the autumn of 1939, the film resonated closely with the burning issues of its time while contrasting the monarchy as a self-restraining institution with individuals ready to abuse political power. Such a distinction would be even more crucial as Britain began its gruelling war with Nazi Germany, and so would the sacrifice of Elizabeth to abandon self-fulfilment be understood as a genuine act of patriotism - a moment of empowerment most The Britishs were ready to repeat in their own ways.

Both Korda and Curtiz exploited popular memory of the Tudor-era as an easily convertible 'historical' currency to forge out a hero/heroine who can serve a strong identification point for British national sentiments. More recently Shekar Kapur's Elizabeth: The Golden Age mythologized and glamourized the queen by updating the private life formula and re-semiotizing the image of the monarchy to fit both modern audience tastes and the contemporary cultural climate. Elizabeth's portrayal merges the qualities and attitudes of an ageless, voguish freethinker of a fearsome femininity - smoking, flirting, wearing tight body armor reminiscent of Arthurian court fashion, giving lessons in dance choreography - with that of the graceful grandmother figure sharing with the nation the more traditional values of solidarity, safety, home. In agreement with Maya Luckett, according to whom 
"the film might be seen in the context of Tony Blair's attempts to update the monarchy by demonstrating how the image of a monarch might produce national renown" $(2000,91)$, I also believe that in this film the cultural markers and ideological discourses of 'Rule Britannia' and 'Cool Britannia' enter into a playful coexistence and render legible Elizabeth's character as a symbolic discursive site where previously antagonistic versions of Britishness are reconciled.

Changing sociocultural attitudes towards gender leave the strongest mark on cinema's historical imagination. Recent Tudor-films explicitly contest the mythologizing approach and phallocratic representations of their predecessors. In their resistance towards populist narratives of masculine empowerment, these films reject - first and foremost - former stereotypes, hierarchies, and discourses of male dominance and re-inscribe into the (cinematic) memory of Tudor England the contemporary crisis of masculinity. Pete Travis's 2003 television film Henry VIII offers little masculine empowerment and portrays the birth of each female baby as a challenge for the supremacy of male history. The instability and partial debasement of such history is also accentuated by the fact that the failure of wives to bear boys or satisfy Henry's other desires results not only in the elimination of women but leads to Henry's male companions falling from grace: Cardinal Thomas Wolsey and Thomas Moore (with Catherine of Aragon), George Boleyn (with Ann Boleyn), Thomas Cromwell (with Ann of Cleves), Thomas Culpeper and the Duke of Norfolk (with Catherine Howard).

Philippa Lowthorpe's TV movie The Other Boleyn Girl (2003, BBC) goes furthest in this regard and takes an unromantic and demythologizing look at the body politics of Tudor court in a cinematic narrative which itself resists glamourizing representation and in its stylistic solutions follows on the path of DOGME 95 aesthetics. The film - underlined by its strong home video-like cinematography (handheld camera, oblique angels, arbitrary mise-en-scènes, onlocation sound, and little musical score) - offers a sensitive reading of how the Boleyn girls' bodies are owned by their family and turned into assets traded for the loyalty of the monarch. The older of the girls, the already wedded Mary, gains independence by becoming Henry's lover and the mother of one of his illegitimate children, and it is exactly this illegitimacy that liberates her body from public constrains, those her sister will fall a victim of. Anne uses her body in an openly ambitious way; she preserves her virginity in order to be eligible for the position of the Queen. She plays by the rules of official body politics the chief trope of which is the synecdoche. No other time in the history of the British Isles would it be more of a central issue whether a marriage is consummated, never was the 
hymen so precious a piece of flesh than under Henry's reign. ${ }^{4}$ The hymen served as an invisible skin safeguarding and also defining pre-marriage femininity, a taboo that made the female body untouchable but for the king, a skin that allowed royal history to be inscribed onto the female body. However Anne's body not only undergoes a synecdochic reduction and will be identified as 'the skin of history (as possession),' since after her marriage to Henry it is further transformed into a royal womb, something no longer intimate and private but a public asset out of which the future is supposed to take shape. She will soon discover that the royal womb is no ordinary womb, and unless it nurtures a male heir to life and serves as a seed of historical continuity, it is doomed to be identified as waste. As Anne Boleyn's historical case suggests, royal femininity is made meaningful through the very framework of functionality which ensures the genesis and establishes the superiority of male history, in other words, the body of the queen is conceptually constructed in a manner that it is always already subordinated to (the logic) of a masculine order. The depiction of the private sphere ceases to be humanizing, in fact, it renders visible the most dehumanizing aspect of one's identity: the loss of corporeal intimacy. The very functionality of the public/institutional roles degrades the female body to the synecdochic-symbolic relationship of the hymen as the skin of history and womb as the seed of history, only to be further reduced to the waste of history. As such Lowthorpe challenges the popular image of Tudor Henry, calls attention to ways in which corporeal femininity is silenced and suppressed within monumental representations of the past, and - contextualized within my present inquiry - suggests that mythologizing/ glamourizing empowerment narratives rigidify rather than modify values, hinder and not promote change. Does this mean that such revisionist films lack to offer empowerment of any kind? Not at all, in fact they urge us to break away from the spell of romantic-nostalgic representations of the past, to examine the masculine logic underlying history, and to revisit those traumatic sites of history where the materiality of the female body was appropriated by history. Empowerment germinates as soon as we understand how history itself is brought into being by this very appropriation.

4 To annul his marriage with Catherine of Aragon, Henry argued that her marriage with his older brother, Arthur, has been consummated. According to Catholic Canon Law this would have annulled his marriage with Catherine. Later, his fourth marriage to Anne of Cleves was annulled after both sides confirmed that the marriage was never consummated. 


\section{The Psychologizing Approach}

Monarchy films about more recent British rulers expand on the dichotomy of the private and the public less critically, yet show full awareness towards the dramatic changes in values, beliefs, lifestyles and consumption patterns that have occurred since the 1930s. These films are mirrors of an era when the public demand for self-conscious images grew, just as the popularity of royal family members - similar to politicians and celebrities - was frequently measured by opinion polls. This was also a period when increasing numbers began to regard the monarchy as part of the heritage industry, or thought that its primary contribution to British society should be the safeguarding of traditional values, like the family: even if this concept was going through a decisive change.

Classical depictions of Queen Victoria - namely Victoria the Great (Herbert Wilcox, 1937) and Sixty Glorious Years (Herbert Wilcox, 1938) - were narratives of empowerment "foregrounding the successful combination of royal duty and married life" (McKechnie 2002, 226). More recent films detach themselves from such idealizing representations and no longer speak of the peaceful coexistence of the public and the private identity, thus "the simple, mythologized image of Victoria the Great is replaced by a more complex representation which includes psychological insights and the element of romance" (McKechnie 2002, 227). A common feature of psychological representation in films like Mrs Brown, The Queen, and The King's Speech is the focus on the monarchs' temporary loss of faith in their institutional persona. Their psychic frailty (either prompted by the death of a family member or speech defunct) is best grasped as the condition of being torn between their self-image and their public image. Such a crisis psychologizes rather than mythologizes human characteristics, which is a way of arguing that these characters are humanized in their identity crises and confrontation with their image.

Empowerment through psychologization clearly signifies a paradigmatic shift within the genre but also gives recognition to (and as such is a side-effect of) the changing view of the monarchy, itself a consequence of Princess Diana's highly publicised and scandal-ridden break with The Windsors. In those days history was written and consumed through tabloids, news coverage, and interviews, it was something immediate, touchable, demanding response. And never evident, in fact, the key to Diana's image is its openness to "multiple and often contradictory investments, calling up notions of royal and non-royal, ordinary and extraordinary, Englishness, Britishness, nationality and the international, of feminist icon and 
patriarchal phantasm, femininity as lived experience and Woman as abstract symbol" (Davies 2001, 135), that is, it occupied a semiotic field open to a multiplicity of meanings: the site of ambiguity. This ambiguity - no longer seen as a frailty - led many to praise Diana for bringing to surface the everywoman within the princess, and to compliment her for being someone who could (both literally and figuratively) touch and be touched by people. As such her desire to "rescue femininity-as-personal-feeling from its imprisonment in the Palace" (Davies, 106) was recognized as the central element of her feminist empowerment. Diana's legacy remains ambiguous partially because it has inspired and keeps inspiring historical narratives in which the status of the monarchy and the position of the monarch are both unstable. In Jean-Marc Vallée's The Young Victoria (2009) the adolescent queen - reminiscent of Diana's later years - expresses herself through compassion, style, and charisma, behaves through instinct rather than rationality and adopts a spontaneous and fluid identity which defies the tightly controlled functions she is supposed to act out as future monarch. Cinema constructs and mediates a Diana-esque Victoria capable of touching people in profound and humane ways, an energetic and forceful personality beneath the traditional image of Victoria as the grandmother-figure of the nation.

Ambiguities surrounding the character of Queen Victoria in Mrs Brown arise from her being torn between the desire for privacy and institutional responsibilities made evident by her preference for Balmoral over Buckingham Palace, the vast spaces of the masculine Scottish Highland over the claustrophobic study, writing her diary over dealing with public affairs, and a cottage dinner over a high profile banquet. Victoria, in her plight to embrace 'femininity-as-personal-feeling,' braves a hypocrite court constantly reminding her of public expectations and allows herself to be immersed by romantic Scotland, this pastoral and pre-modern Britain where she develops a close - and in the eyes of many, scandalous - friendship and admiration for John Brown, an ingenuous yet faithful male servant. The romantic portrayal of their friendship renders the notions of master and servant, affection and pragmatism, alienation and self-exploration ambiguous, and also serves as a narrative tool to dramatize and psychologize the queen's crisis. Such a representation - I believe - is a direct product of the 1990s when the idealized (and official) image of the monarchy came tumbling down and people discovered a human reality behind the fences of Palace, a familiar reality they could identify with. The British discovered the Windsors to be their contemporaries, flesh and blood people who were immune neither to the crisis of values and ideals nor the changing life-styles and the ambiguities it brought about. Mrs Brown revisits 
an episode of Queen Victoria's rule marred by the scandal of her ambiguous relationship with Brown, nevertheless it portrays this crisis from inside, revealing the psychological mechanisms of a mind, first traumatized by loss and alienation, but later rejuvenated by emotional bonding and self-discovery. The psychologizing formula develops into an empowerment narrative as the queen understand that it is her human qualities and not historical necessity, her natural devotion as opposed to public expectations that makes one a monarch.

\section{Psychologizing, Empowerment, and Self-Reflexivity in The Queen}

Stephen Frears's The Queen addresses Diana's heritage ever more directly, retelling the week's incidents following her death on 31 August, 1997. Almost a decade after the actual events took place the film revisits this traumatic site of memory, a threshold between historical and living memory, "an instance of history in the making” (Vidal 2012, 38). Frears understands all too well that most of us remember the newspaper headlines, television broadcasts, and speeches as if they happened yesterday, that this mediated event and its iconic images cannot be fully historicised. ${ }^{5}$ The film blends the immediacy and 'on-the-spot'ness of original footage with aestheticized and dramatized representations in a sensitive manner and makes in them reflected the conflict of private life and public duties: the dichotomy lying at the heart of the queen's identity crisis. Already in the first scene two types of visual frames - the news footage on TV and the half-finished portrait of the queen on the canvas - emphasize two regimes of images, one bringing the world into one's living room, forcing sensationalist, lowresolution, yet collective and energetic images onto the viewer, the other offering a flawless, painterly vision of a privacy which nevertheless seems distant, cold, dead. The first reaches out towards the viewer as a haptic presence waiting to be

$5 \quad$ While 'historical distance' is somewhat lacking, the film's portrayal of the royal family as a historical institution is fully justified. Vidal's analysis calls attention to ways Frears adopts a nostalgic mode of address in his presentation of the heydays of Tony Blair's (and his party's) political intelligence. Bearing in mind that nostalgia is a memory-technique grounded on the clear distinction between past and present (a yearning for a past based on something missing from the present), we can see how the Queen's cautioning the PM about the changefulness of popularity (as a sign of her own 'historical intelligence') finds expression in the film. As Vidal argues: "Ultimately, the sharp sense of irony in The Queen arises, not just from the spectacle of the past that fails to fall into step with the present, but also from the present (the period of New Labour government reframed as the past) to live up to its promise" (Vidal 2012, 47). 
absorbed, the second favours disembodied vision, prefers only to be observed and functions as a "fetish tableau" (Vidal 2012, 42). Distinct as they are, these iconic regimes come into contact and overcode each other in the film that can be considered a narrative of an iconic transfiguration: whereas at the beginning she is identified in the context of the portrait, the film practically ends with her broadcasted image. I regard the queen's transformation as the mirror of more extensive transformations the monarchy - as a historical institution, but also as political, legal, and symbolic body - underwent in the aftermath of Diana's death as it encountered a crisis of making itself meaningful, as its semiotic field, believed to be stable, was directly contested.

Frears uses the original news footage of the mourning crowd and their raw emotionality to monumentalize and inscribe the loss of Diana into the physical and symbolic spatiality of Buckingham Palace, whereas the composure and decorum of picturesque Balmoral Palace and its empty spaces signal the identity crisis of the queen. Shots of her in the company of hunting dogs, her figure dwarfed in the enormous kitchen or the palace garden do not work as realist depictions of an average person in everyday situations; her physical isolation is always already linked to the presumed emptiness of the Establishment, the weakening moral support of the people and her failing popularity as a reassuring symbol of Britishness. In fact these images semiotize and spatialize her presence as something rather belonging to the fine elegance of the painterly compositions than to a lived reality: she is depicted as a left-over of antiquarian history, someone alienated and untouchable. Furthermore, reappearing shots of the queen among dogs locates her presence closer to the tender-minded, sentimental, and Romantic $19^{\text {th }}$ century world of Sir Edwin Landseer than the late $20^{\text {th }}$. Fixed within these art-historicizing 'canvases' the queen seems more lifeless than Diana, who, although physically absent, is the very force animating the present.

To this point my analysis offered similar insights into the film as Belén Vidal's own reading of The Queen, I will now turn my attention to the psychologizing strategies of the narrative. I believe that visual markers of the queen's spatial alienation are used by Frears in their capacity to make legible her inner turmoil. Psychologizing or humanizing the character involves, one the one hand, linking the queen's identity crisis to the antagonism of the private and the institutional personae, and on the other hand, making audiences aware of those principles and values - a respect for intimacy and tradition, an adherence for protocols and ceremoniality, emotional restraint and discreet mourning - that shape the royal family's pragmatic attitudes in the aftermath of the tragedy. The queen's 
identity crisis will be resolved as she understands that the unpopularity and media-induced vilification of these principles is less a challenge on her moral integrity than the institution of the monarchy. In other words: the queen might be right to regard herself morally superior to the manipulative and hysterical modernity of celebrity culture propagated by the media and embraced by the majority of the population, yet she is responsible for the Crown, its symbolic powers and historical continuity. Discovering that her conflict with false ideals is really a conflict between her private and institutional identity, the queen also realizes that part of her identity falls outside her personal control.

The central role of Prime Minister Tony Blair (Queen Elizabeth's own rather sentimental John Brown) and his mediatory activities to evade a full-blown constitutional crisis might suggest that her identity crisis is resolved from the outside, as an involuntary submission to realpolitik. Yet Frears refuses to offer such a functionalist, defeatist, and unromantic notion of the monarchy; on the contrary, the film's most intimate and sentimental scene, the queen's encounter with a majestic royal stag in the Scottish Highlands, serves as a catalyst of her climactic transformation. More than a sequence with unmistakable painterly qualities, the encounter takes place 'within' Landseer's Monarch of the Glen $(1851)^{6}$ [Fig. 1], the portrait of an anthropomorphized, 'monarchified' deer. The filmmaker reproduces the painting as a cinematic composition [Fig. 2] and extends the sequence towards a shot which simultaneously uses hard-focus and soft-focus photography [Fig. 3], making distinguishable a dominant (optical, remote) and a secondary (haptic, imminent) figure but also introducing into the composition a doubling and othering effect. In the last composition our eyes trace the painterly space along the diagonal axis, hence signification is realized through the perspective of the queen, occupying the blurred space of 'the other.' Her spatial position serves as a point of identification, evolving involvement and responsibility for the stag. One literally sees two monarchs in this frame and the intensity of their co-presence is not only spatial but symbolical. Their identicalness, on the one hand, alludes to the shared fate of the two entities but, on the other hand, points to the psychological moment of identifying oneself with one's 'other,' or for that matter, honouring subliminal otherness as one's own. In my understanding it is through the imposing and empowering image of

$6 \quad$ Mrs Brown also makes extensive use of Landseer's painterly universe and that of his disciple Charles Burton Barber. Nevertheless his Queen Victoria at Osborne House (1965) and Barber's Queen Victoria with John Brown are used as mere illustrative resources and are not 'woven into' the cinematic images in such a self-reflexive manner as with Frears. 
the stag (as a symbol of dignity) does she discover and embrace her own symbolic other, the institutional identity she has been trying to repress. In a sense she realizes that the monarchy is just as much an integral part of Britishness as the stag belongs to the landscape, without which it would be incomplete, pathetic, unaccomplished. If Frears depicts the encounter as a kind of 'magic moment,' he only does so to accentuate the queen's inner transformation of becoming sensitive to her 'other,' the part of her personality that must touch people the same way she was touched by the radiant presence of the stag.

Frears portrays the newly found equilibrium between the monarch and the people - as the royal party joins the commemorating crowd outside Buckingham Palace in a sequence with optical and haptic images entering into a new relationship. The first shot is taken from original news footage followed by images photographed on low-res film stock (with a video-image-like feel to it), and the sequence is concluded by frames of standard quality. Frears's conceptual use of different resolutions and textures accentuates the tension as the queen gradually enters the consensual space of the commemorators, slowly walks towards the crowd and comes within touching distance (both spatially and symbolically). She crosses the threshold beyond which communal/excessive remembering and individual/subdued mourning fade into each other, where the living drama of the moment is not yet historicised and the week-long crisis of confidence evolves into an empowerment narrative. Crossing this threshold, Frears might conclude, cherishing Diana's memory becomes a shared responsibility and her legacy - in the wish of a more accessible and spontaneous monarchy - inscribed into British identity.

\section{Conclusions: The King's Speech}

I regard The King's Speech, my last example, the most mature and acknowledged ${ }^{7}$ of recent monarchy films dramatizing the identity crisis of the monarch and addressing the antagonism between private and institutional personae through an empowerment narrative. By mature I simply mean the clarity with which thematic issues are drawn up and narrative-aesthetic effects are employed in order to make British history accessible for global audiences. The best elements of the cinematic profession come together in the final scene of the film as George VI addresses citizens in Britain and the colonies through a radio message after the country

7 With a win-nomination ratio of 4/12 (4 Academy Awards won out of 12 nominations) The King's Speech is ahead of other films in the genre. Similar figures for other films are as follows: The Queen (1/6), The Young Victoria (1/3) Elizabeth (1/7), Elizabeth: The Golden Age (1/3), and Mrs Brown (0/2). 
declares war on Germany. Relying on a historical document (the recording of the king's actual broadcast), this sequence is a vivid example how fine moments of the past are dramatized, how empowerment is extended towards the future in this case - within a triple framework: as (1) self-transcendence for a person suffering from speech disorder, (2) the advent of unity for the nation which stands supportive of its institutions, and (3) a second of clarity for liberal democracy as far as its core values and principles are concerned. The King's Speech historicizes the empowerment of private and national identity and capitalizes on the elemental forces working within nostalgia and the sentimental yearning for the generation of Britons who have taken an active part in WWII, yet it does not remediate this monumental past as something shaped by impersonal historical forces, instead concentrates on the personal and quotidian aspects of history.

The film makes numerous references to the British political and sociocultural context in order to situate its hero, yet George VI is individuated through his traumatised identity. Stammering is the most evident symptom of his injured selfimage, a direct consequence of having been brought up at the royal court where his body was made painfully aware of its institutional role and image as an adult. Being forced to wear painful corrective splints for his knock knees and required to write with a right hand (although born left-handed) gave an early lesson to George in how the normativizing forces of history are inscribed onto one's body, how bodies are prepared for history. As a result of these traumatic interventions his speech organs literally revolt against the public voice he is expected to act out. His voice is the wound, the pre-linguistic orality, the noisy babbling, the fractured verbality as opposed to the flawless musicality of eloquent oratory. How does one arrive from the former to the latter and play along norms and rules that make him ill? Well exactly in this manner, by playing along, by liberating the child that has been supressed and silenced, by returning part of the self to the pre-traumatic, pre-Oedipal, 'other' existence, where Oedipus is not just the authoritative father (persistently haunting the adult George) but History itself. If Lionel Logue's speech therapy is unorthodox, it is for no other reason, but for being a unique psychotherapy; a technique that teaches the king how to play along institutional obligations as part a game, for fun. All this finds expression in the rehearsal for the all-important radio broadcast when we see and hear George the clown, the 'other' of History: an ignorant kid swearing, dancing, singing, and playfully debasing the moral message of his words. In the minutes to follow he will transform from prankster into king, swearing will be censored, singing eliminated, dancing reduced to a static posture, nevertheless his 'other' will only be overlaid and not altogether eliminated and overcoded. 
I have argued above that self-transcending is achieved in a triple framework of the individual, the nation, and the ideology. Cinematic imagination captures this moment by way of orchestrating three axes of dramatic-narrative functions - the Hero, the Act, and the Morality - in the final, glamourizing-lyrical montage sequence of the film depicting a cross-section of British society as it attentively receives George's (Hero) broadcast (Act) of the causes why England declares war on Germany (Moral). These snapshots, reminiscent of genre paintings, reveal faces from various classes and ranks of society, faces that will enter the pages of history as saviours of the nation (Hero) having protected (Act) British lifestyles, values, principles, and belief systems (Moral). But beyond the home and the factory, the barracks and the gentleman's clubs there is yet another location and a community listening to George's word: the cinema Audience. It is here (in the present) that the narrative fully unfolds its empowering effects as spectators become contemporaries of those faces. Historical cinema needs this fourth axis that receives the joint efforts of the other three and raises them to the level of individual, social, political, and ideological empowerment. The King's Speech achieves empowerment by foregrounding a strong psychological narrative, that of self-transcendence. One of its main achievements is the elegance with which it allows us to identify with the character-centred human drama, the other is the powerful manner we are made recipients of heritage as part of a community. It certainly is good to be British! Or is it? At the time of its making, Britain - as all other developed nations - were in the midst of one of their most serious financial crisis, a crisis of confidence regarding the very foundations of our global consumer societies. Fighting the bloodiest war of history certainly requires very different resources and strategies than finding remedies for financial woes, nevertheless both demands social consensus, joint efforts and most of all placing community interests above individual concerns. While working towards these aims history might be the best, if not our only teacher.

I would conclude by saying that what binds the past to the present is the vulnerability and ambiguity of our identities. Each of the analysed films aim for empowerment: as historical narratives they perform, stage, dramatize the past in order to discover through them the values, points of identification and systems of orientation contemporary identities rely on. The past is resemiotized - given a material and abstract existence - along two, often intertwined paradigms, both of which undermine the strict methodological rigour of historiography. Mythologizing the past, rendering historical figures as heroes/heroines of a glamourizing popular memory offers rather didactic and superfluous forms of 
empowerment, similar to the ones consumer culture provides. Psychologizing history, in my understanding, is a more dynamic and complex strategy of empowerment, one in which the antagonism of the intimate and the institutional is resolved through involving and immersive narratives. Either way, for long decades, cinema has drawn inspiration from history and this fascination is unlikely to end any time soon. Forcing our way into the $21^{\text {st }}$ century we cross consecutive thresholds within hypermediality and globalisation, and whereas our identities are likely to become ever more fluid, it might offer reassurance that there will always be a past, a foreign country, waiting patiently to be occupied and serve us with the kind of empowerment we are willing to take.

\section{References}

Chapman, James. 2005. Past and Present: National Identity and the British Historical Film. London: IB Tauris.

Davies, Jude. 2001. Diana, A Cultural History. Gender, Race, Nation and the People's Princess. London: Palgrave Macmillan.

Driver, Martha W. 2004. What's Accuracy Got to Do with It? Historicity and Authenticity in Historical Film. In The Medieval Hero on Screen: Representations from Beowulf to Buffy, eds. Martha W. Driver and Sid Ray, 19-22. Jefferson: McFarland.

Elliot, Andrew B. R. 2011. Remaking the Middle Ages: Methods of Cinema and History in Portraying the Medieval World. Jefferson: McFarland.

Higson, Andrew. 2003. English Heritage, English Cinema: Costume Drama Since 1980. Oxford-New York: University Press.

Higson, Andrew. 2011. Film England: Culturally English Filmmaking Since the 1990s. London/New York: I.B.Tauris.

Lowenthal, David. 1985. The Past is a Foreign Country. Cambridge: Cambridge University Press.

Luckett, Moya. 2000. Image and nation in 1990s British cinema. In British Cinema of the 1990s, ed. Robert Murphy, 88-99. London: BFI.

Marks, Laura U. 2000. The Skin of the Film: Intercultural Cinema, Embodiment, and the Senses. Durham: Duke University Press.

Marks, Laura U. 2002. Touch: Sensuous Theory and Multisensory Media. Minneapolis: Michigan University Press.

Marx, Karl. 2002. The Leading Article of No. 179 of Kölnische Zeitung. In Marx on Religion, ed. John Raines, 28-44. Philadelphia: Temple University Press. 
McKechnie, Kara. 2002. Taking Liberties with the Monarch: the Royal Bio-Pic in the 1990s. In British Historical Cinema, eds. Claire Monk and Amy Sargeant, 217-236. London: Routledge.

Nietzsche, Friedrich. 1980. On the Advantage and Disadvantage of History for Life. Indianapolis/Cambridge: Hackett Publishing Company.

Vidal, Belén. 2012. Heritage Film: Nation, Genre and Representation. New York/ Chichester: Wallflower Press/Columbia University Press.

\section{List of Figures}

Figures 1-2. Edwin Landseer's painting, Monarch of the Glen (1851) reproduced in Stephen Frears's The Queen.
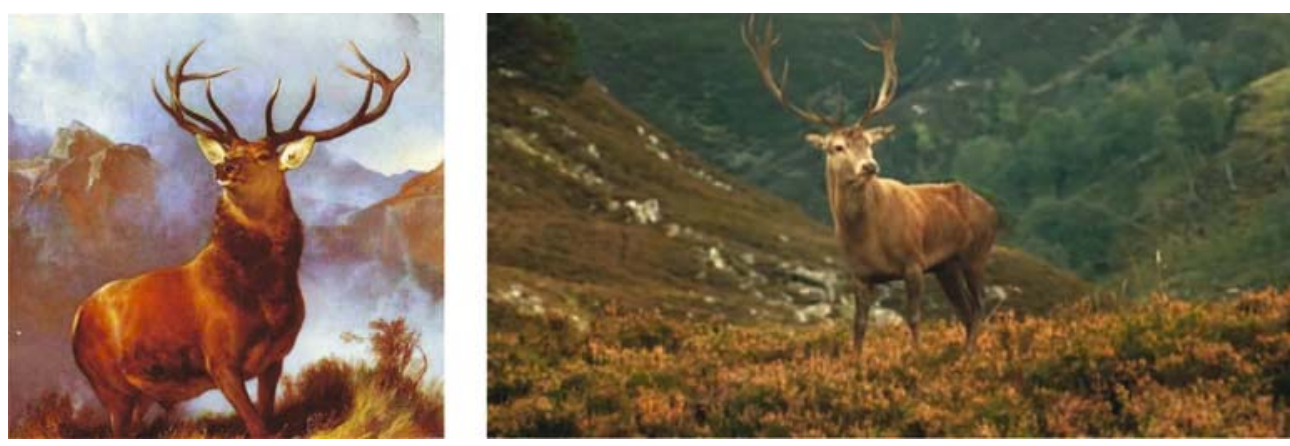